\title{
DEPOT NÁRAMKOV Z DOBY HALŠTATSKEJ Z VRCHU ZÁRUBY V MALÝCH KARPATOCH ${ }^{1}$
}

\author{
R A D O L AV ČA MBA L - ERIKA M A K A ROVÁ
}

\begin{abstract}
Hoard of Bracelets from the Hallstatt Period from the Záruby Peak in the Little Carpathians. Paper deals with a hoard of three bronze spiral rings passed to the collection of the SNM-Archaeological museum in Bratislava in 2004. They were found on the Záruby, the highest peak and the dominant of the Little Carpathians, in the cadastral district of Buková and Smolenice. The alleged location of the hoard almost on the top of the hill might point to the possibility of its ritual deposition. The spiral bracelets made of bronze wire with decorated ends date to the stage HD.
\end{abstract}

Keywords: SW Slovakia, Little Carpathians, Hallstatt period, hoard, spiral bracelet, XRF analysis.

\section{ÚVOD}

V roku 2004 bol do zbierok SNM-Archeologického múzea v Bratislave odovzdaný depot troch špirálovitých náramkov zhotovených z bronzového drôtu. ${ }^{2}$ Tie boli nájdené na Zárubách (kóta 747,4), najvyššom vrchu a dominante Malých Karpát, v katastrálnom území obcí Buková a Smolenice (obr. 1). Hromadný nález sa údajne našiel takmer pod vrcholom kopca. Bližšie nálezové okolnosti ani kontext, v akom usporiadaní boli predmety v zemi uložené, prípadne prítomnost' iných artefaktov, nám nie sú známe. To do značnej miery limituje vyhodnotenie depotu. Depot bol už predbežne publikovaný, avšak bez vyhodnotenia (Farkaš 2018, 5, obr. na str. 5, vlavo dole).

Bukovská brázda, v minulosti známa ako Biksádsky priesmyk (Farkaš 2018, 4), patrila a dodnes patrí k najdôležitejším a zároveň najvytaženejším prechodom cez Malé Karpaty. Ide o strategicky významný karpatský prechod. Dokladom toho je v súčasnosti pomerne vela známych archeologických nálezov $\mathrm{z}$ rôznych polôh $\mathrm{v}$ priesmyku a jeho blízkom okolí z časových úsekov od praveku až po vrcholný stredovek, resp. novovek. ${ }^{3} \mathrm{Z}$ obdobia strednej doby bronzovej sa tu nachádza pohrebisko stredodunajskej mohylovej kultúry, preskúmané v polohe Hrúdy, podobne aj v ned’alekých Smoleniciach (Bobek 2016, 34-36; Dušek 1980, 366). Z mladšej doby bronzovej sú z katastra Bukovej známe dva hromadné nálezy bronzových predmetov. Jeden označený ako Buková I pochádza z polohy Skalka a je datovaný do BD-HA2. Druhý hromadný nález - Buková II - bol nájdený v polohe Kmen- tová a spadá do stupňov BD-HA1 (Bartík/Farkašl Jelinek 2019, 21-26). Z obdobia strednej a neskorej doby laténskej sú známe rôzne nálezy od militárií, súčastí odevu až po numizmatické nálezy (Čambal 2008, 241-248; 2017, 7-10; Čambal 2020, v tlači). Z doby rímskej odtial' pochádza plastika sediacej bohyne Minervy (Kvetánová 2008, 111-124). V stredoveku tam bol postavený hrad Ostrý kameň, z ktorého pochádzajú taktiež zaujímavé nálezy vrcholnostredovekých militárií (Čambal 2011, 159-163; Kováč 2006, 361-368). Z priesmyku, konkrétne z polohy Biela hora, pochádza aj niekol'ko pokladov stredovekých mincí, ktoré súvisia s už spomínanou stredovekou Českou cestou, ktorej význam vzrástol od 30-tych rokov 14. storočia. Navyše sa v tomto priesmyku nachádzala aj colná stanica (Budaj 2006, 304, 305).

\section{Opis predmetov}

1. Drôtený bronzový špirálovitý náramok, zložený zo štyroch a polovice závitov, husto vedla seba navinutých, na oboch koncoch ukončený profilovanými koncami v podobe štvorice vývalkov, vyrobených pomocou štyroch rýh (obr. 2: 1a, 1b). Náramok je pokrytý súvislou kvalitnou tmavozelenou patinou. Rozmery: priemer drôtu 2,0-2,11 mm; vnútorný priemer náramku 6,3-6,4 cm, vonkajší priemer náramku 6,8-6,9cm, hmotnost' 31,92 g (evid. č. AP 75 749).

2. Drôtený bronzový špirálovitý náramok, zložený zo štyroch a polovice závitov, husto na seba navinutých, na oboch koncoch žalud'ovito ukončený (obr. 2: 2a, 2b). Náramok je pokrytý súvislou kvalitnou tmavozelenou patinou. Rozmery: priemer drôtu 2,0 mm; vnútorný priemer náramku 6,96-6,84 cm, vonkajší priemer náramku 7,33-7,4 cm, hmotnost' 35,30 g (evid. č. AP 75750 ).

\footnotetext{
1 Táto práca bola podporovaná Agentúrou na podporu výskumu a vývoja na základe Zmluvy č. APVV-15-0491.

2 Predmety sú uložené v zbierkach Slovenského národného múzea-Archeologického múzea v Bratislave pod evidenčnými číslami AP 75749-AP 75751.

3 Ústna informácia od Z. Farkaša (SNM-Archeologické múzeum v Bratislave).
} 


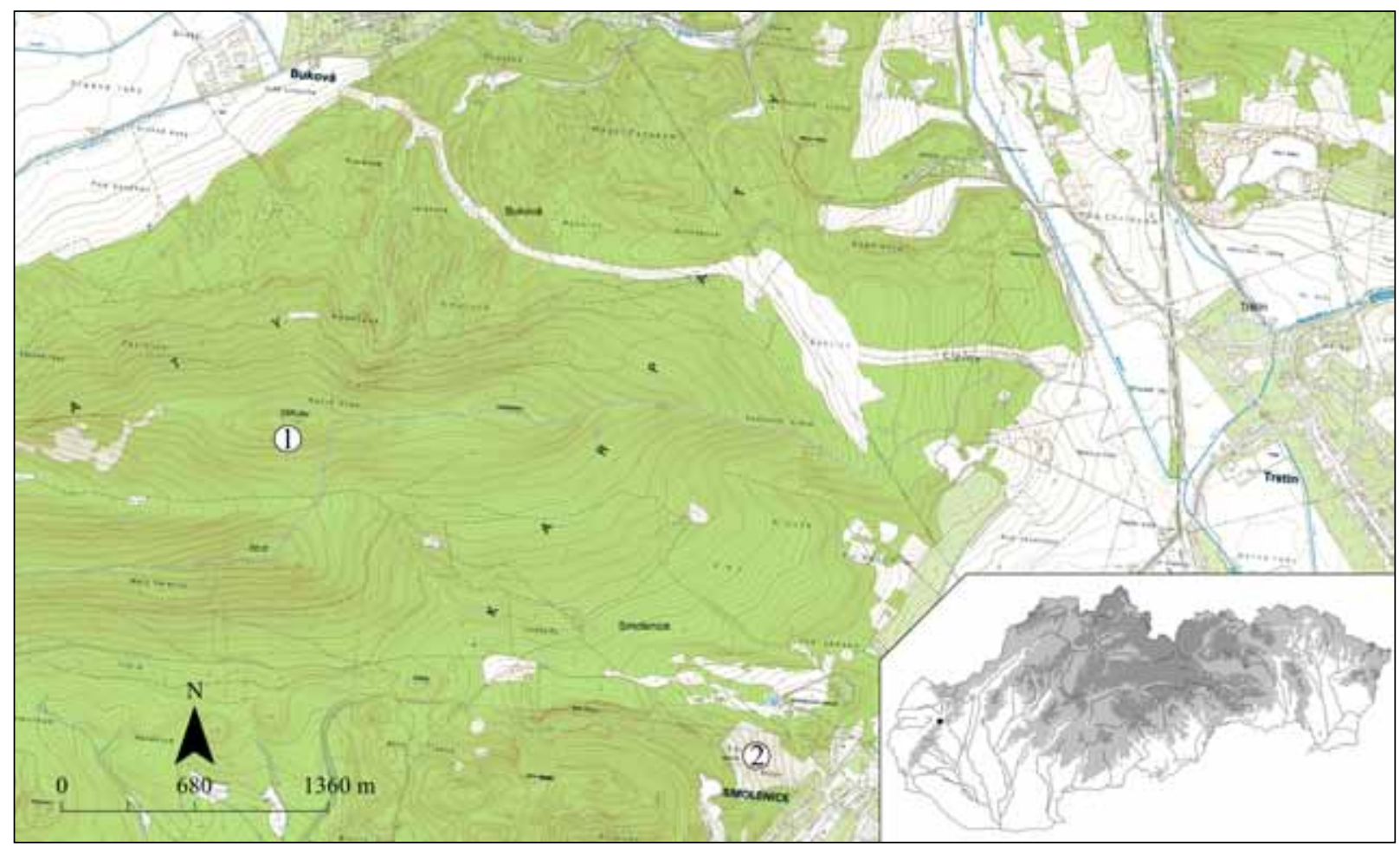

Obr. 1. Masív Malých Karpát v k. ú. Buková a Smolenice. 1 - situovanie nálezu depotu náramkov na vrchu Záruby; 2 hradisko Molpír v Smoleniciach (autor R. Čambal).

3. Drôtený bronzový špirálovitý náramok, zložený zo štyroch závitov, roztiahnutých od seba, na oboch koncoch žalud’ovito ukončený (obr. 2: 3a, 3b). Náramok je pokrytý súvislou kvalitnou tmavozelenou patinou. Rozmery: priemer drôtu 2,12 $\mathrm{mm}$; vnútorný priemer náramku 7,45-7,65 cm, vonkajší priemer náramku 7,8-8,12 cm, hmotnost' 34,65 g (evid. č. AP 75 751).

\section{CHEMICKÉ ZLOŽENIE NÁRAMKOV}

U všetkých troch náramkov bolo skúmané elementárne prvkové zloženie. Na meranie bol použitý ručný XRF analyzátor NITON XL3t od firmy Thermo Fisher Scientific, NITON z USA. Ten je určený pre nedeštruktívne analýzy chemického zloženia predmetov, pričom meranie sa uskutočňuje z povrchu skúmaného predmetu. Každý náramok bol meraný na dvoch miestach s dobou merania 30 sekúnd, pričom bola analyzovaná tak vrstva pokrytá patinou, ako aj miesto, kde bola brúsnym papierom odstránená patina až na pôvodný kov. ${ }^{4}$

Výsledky spektrálnej röntgenovej analýzy (tabela 1) ukázali, že prvkové zloženie je u všetkých troch náramkov vel'mi podobné, hoci mierne odchýlky sa u oboch variantov náramkov objavili. Zatial čo náramok s viacnásobne profilovanými koncami má v porovnaní s náramkami so žalud’ovitými koncami o čosi nižšie zastúpenie medi a olova a vyššie zastúpenie cínu, oba náramky so žalud’ovitými koncami majú percentuálne zastúpenie jednotlivých prvkov velmi podobné.

\section{VYHODNOTENIE NÁLEZOV}

Najbližšími analógiami trojice špirálovitých náramkov zo Zárub sú nálezy z hradiska Molpír v Smoleniciach. K náramku č. 1, ktorý je ukončený viacnásobne profilovanými koncami, patrí identický nález z brány IV (Dušek/Dušek 1995, tab. 88: 17). $\mathrm{K}$ ostatným dvom náramkom, ktoré majú jednoduché žalud'ovité ukončenie, pravdepodobne patrí fragment náramku z domu 4 (Dušek/Dušek 1984, tab. 37: 14). Navyše, zo smolenického Molpíra pochádza viacero typologicky podobných nálezov špirálovitých náramkov. Tie však, ako sa zdá, nemajú nijak profilované ukončenie. Ide napríklad o nálezy náramkov z domu 8 (Dušek/Dušek 1984, tab. 53: 7), 16 (Dušek/Dušek 1984, tab. 114: 15, 16; 116: 27, 28) a 32 (Dušek/Dušek 1995, tab. 34: 4), z kul-

\footnotetext{
4 Za relevantné sa však brali len výsledky analýzy z miesta pôvodného kovu, ked’že patina na povrchu býva zväčša kontaminovaná, a tým pádom je ich vypovedacia hodnota značne znížená.
} 


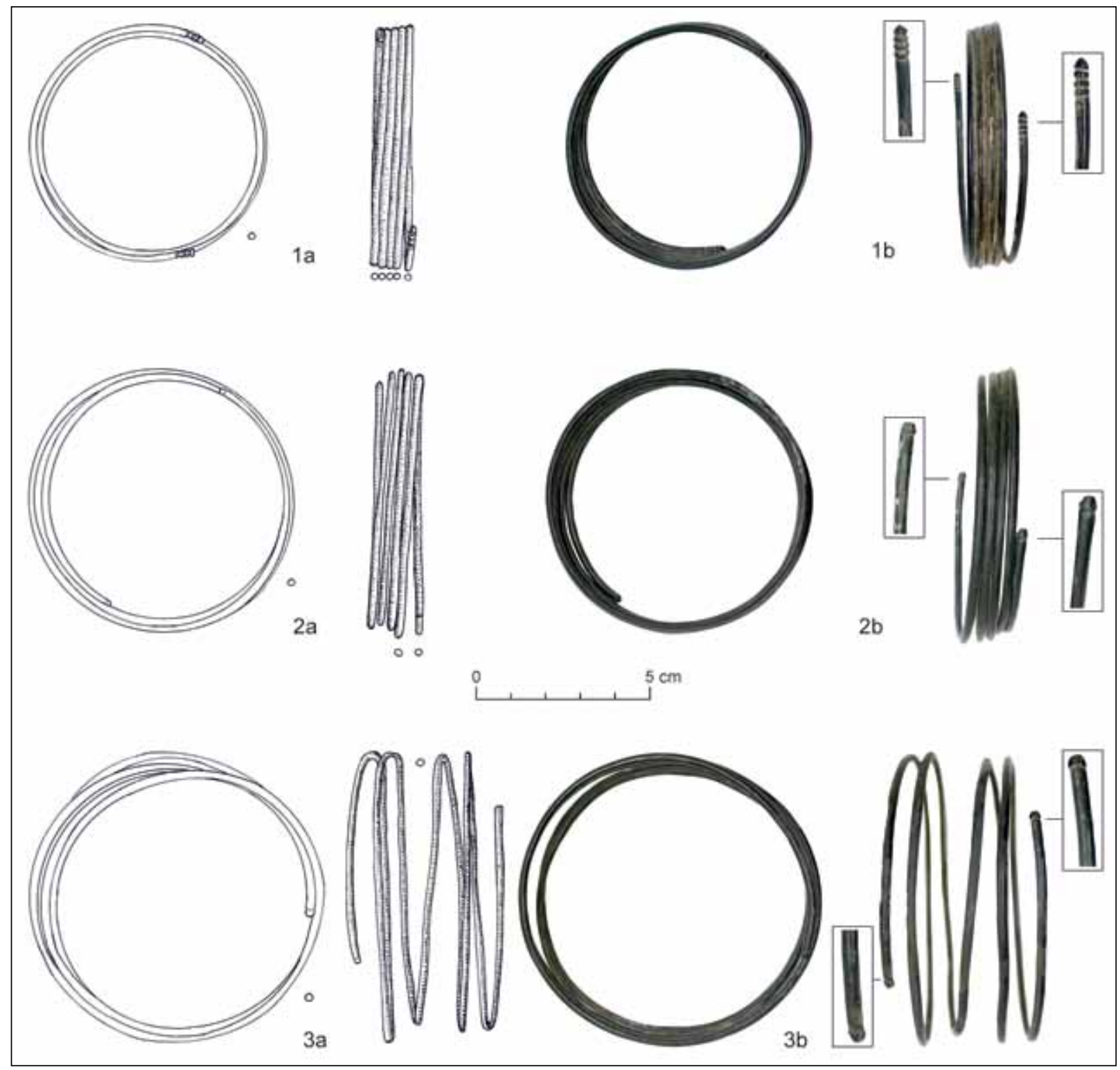

Obr. 2. Záruby, k. ú. Buková a Smolenice. Depot bronzových náramkov (kresby: archív SNM-AM v Bratislave, foto R. Čambal).

tového miesta (Dušek/Dušek 1995, tab 45: 9) či z brány IV (Dušek/Dušek 1995, tab. 90: 24, 25).

Špirálovité náramky a menšie krúžky (záušnice?) z bronzového drôtu sa vo väčšom počte našli aj v jaskyni Býčí skála (Parzinger 1995, 45, 46, tab. 15-17), pričom sa i medzi nimi nachádzali oba varianty, a to exempláre so žalud'ovitým ukončením (Parzinger 1995, tab. 16: 144, 151, 155, 156; 17: 171) a s koncami zdobenými obežnými ryhami (Parzinger 1995, tab. 16: 152; 17: 160, 163, 170, 177, 178, 185). Bronzové špirálovité náramky so žalud’ovitým ukončením boli súčastou aj dvoch depotov z prostredia platěnickej kultúry na Morave. V depote, ktorý sa našiel na hradisku Rýsov pri Provodove (okr. Zlín), boli štyri exempláre (Čižmář/Čižmářová 2014, obr. 9: 6-9) spolu s dalšími šperkami, a to štyrmi bronzovými uzatvorenými náramkami s priečnymi rebrami, 29 sklenými a 33 jantárovými korálikmi (Čižmářl Čižmářová 2014, 47-50, obr. 9; 10). Dva náramky tohto variantu sa objavili aj v depote, ktorý bol odkrytý v areáli sídliska v Prostějove-Čechůvkach. Svojou skladbou sa podobal predošlému depotu - okrem už spomínaných špirálovitých náramkov obsahoval dva uzatvorené náramky s priečnymi rebrami, jeden otvorený náramok zdobený rytou výzdobou a väčší počet jantárových a perletových korálikov (Čižmár̆) Geislerová 2006, 258, 259; Přichystal/Kos 2006, 50; Šmíd 2005). Uzatvorené liate rebrované náramky 


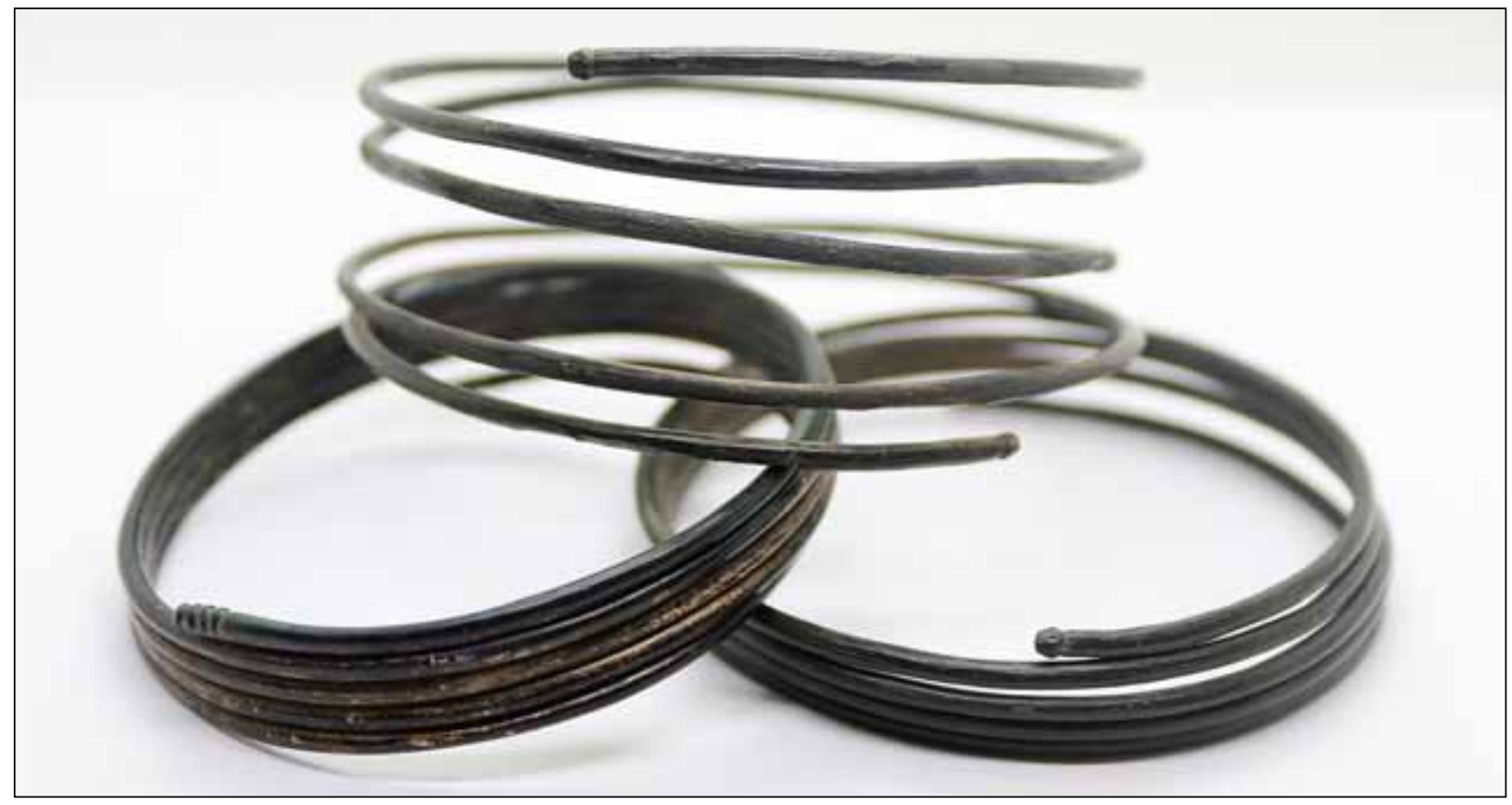

Obr. 3. Záruby, k. ú. Buková a Smolenice. Depot bronzových náramkov (foto R. Čambal).

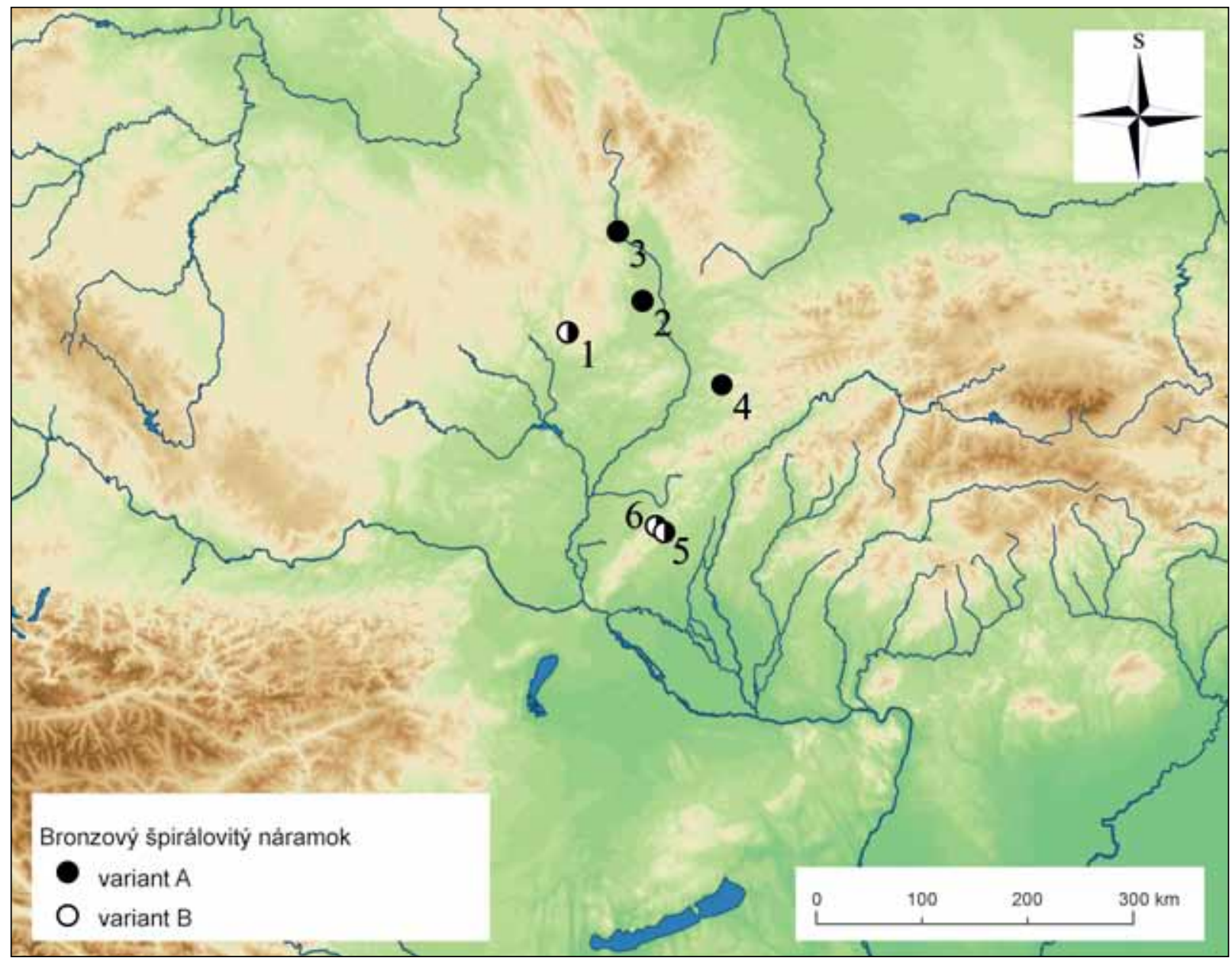

Obr. 4. Mapa rozšírenia špirálovitých náramkov z bronzového drôtu. 1 - Býčí skála; 2 -Prostějov-Čechůvky; 3-Moravičany; 4 - Rýsov u Povodova; 5 - Smolenice-Molpír; 6 - Záruby. Legenda: variant A - so žaludovito ukončenými koncami; variant $\mathrm{B}$ - s profilovanými koncami (autor E. Makarová). 
Tabela 1. Záruby, k. ú. Buková a Smolenice. Chemické zloženie náramkov. Výsledky merania metódou XRF (meral R. Čambal).

\begin{tabular}{|c|c|c|c|c|c|c|c|c|c|c|c|}
\hline & \multicolumn{11}{|c|}{ Druh a percentuálne zastúpenie jednotlivých kovov $v$ analyzovaných predmetoch } \\
\hline & $\mathrm{Cu}$ & Sn & $\mathrm{Pb}$ & $\mathrm{Au}$ & Ag & $\mathrm{Ni}$ & $\mathrm{Fe}$ & $\mathrm{Zn}$ & Co & Sb & $\mathbf{B i}$ \\
\hline $\begin{array}{l}\text { Náramok č. } 1 \\
\text { (obr. 2: 1a, b) } 1\end{array}$ & 78,7 & 18,63 & 0,656 & - & - & 1,25 & 0,245 & 0,052 & - & - & - \\
\hline $\begin{array}{c}\text { Náramok č. } 1 \\
\text { (obr. 2: 1a, b) } 2\end{array}$ & 86,23 & 11,75 & 0,529 & - & - & 1 & 0,108 & - & 0,047 & 0,206 & - \\
\hline $\begin{array}{c}\text { Náramok č. } 2 \\
\text { (obr. 2: 2a, b) } 1\end{array}$ & 59,34 & 34,03 & 2,65 & 0,03 & 0,304 & - & 2,3 & - & - & - & - \\
\hline $\begin{array}{c}\text { Náramok č. } 2 \\
\text { (obr. 2: 2a, b) } 2\end{array}$ & 88,69 & 9,82 & 0,908 & - & - & 0,07 & 0,396 & - & 0,046 & - & 0,061 \\
\hline $\begin{array}{l}\text { Náramok č. } 3 \\
\text { (obr. 2: 3a, b) } 1\end{array}$ & 63,44 & 31,21 & 2,29 & - & 0,276 & 0,161 & 1,77 & 0,129 & - & - & - \\
\hline $\begin{array}{c}\text { Náramok č. } 3 \\
\text { (obr. 2: 3a, b) } 2\end{array}$ & 88,15 & 10,17 & 0,893 & - & - & 0,085 & 0,397 & - & 0,054 & 0,079 & 0,083 \\
\hline
\end{tabular}

z obidvoch depotov patria k variantu Býčí skála, datovanému do stupňov HC2-HD1 (pozri Parzinger 1995, 36-38, tab. 10).

Revízia materiálu z halštatskej časti pohrebiska v Moravičanoch (Makarová 2017, 49) ukázala, že s týmto typom šperku sa môžeme stretnút na území rozšírenia platěnickej kultúry aj v hrobových celkoch. Na pohrebisku v Moravičanoch sa totiž spomínané žalud’ovité ukončenie dochovalo na exemplári z hrobu 533, ktorý môže byṫ na základe misky s lomenou výdutou datovaný do stupňa HD. Nie je však vylúčené, že aj iné fragmentárne zachované exempláre pochádzajúce $\mathrm{z}$ d’alších trinástich hrobov mohli patrit $k$ tomuto variantu drôteného šperku. Náramky z bronzového, špirálovite stočeného drôtu, sa objavujú aj na iných pohrebiskách $\mathrm{z}$ doby halštatskej $\mathrm{v}$ širšom stredoeurópskom priestore (Makarová 2017, 47), no zdá sa, že ich ukončenia zdobené nie sú.

\section{ZÁVER}

Depot bronzových náramkov s najväčšou pravdepodobnostou súvisí s halštatským osídlením nedalekého hradiska na Molpíre v Smoleniciach, ktoré je od miesta nálezu náramkov vzdialené $2,5 \mathrm{~km}$ vzdušnou čiarou (obr. 1), a s pohybom obyvatel'stva $\mathrm{v}$ tomto regióne. Hradisko totiž leží jednak v blízkosti Jabloneckého priesmyku, ktorý spája Považie s Pomoravím, jednak na ceste tvoriacej súčast̉ dial'kovej komunikácie spájajúcej juhovýchodoalpskú oblast' so severom (Dušek 1971, 431; Stegmann-Rajtár 2002, 263, 264, obr. 6). Údajné uloženie depotu takmer pod vrcholom kopca by mohlo naznačovat' rituálny podtext jeho uloženia do zeme, avšak vzhladom na chýbajúce bližšie nálezové okolnosti nemáme $\mathrm{k}$ dispozícii identifikačné kritéria, na základe ktorých by sme mohli depot interpretovat (pozri Salaš 2005, 225-238).

Špirálovité náramky s profilovanými koncami a s koncami zdobenými žaludovitým ukončením boli donedávna známe len z územia strednej Moravy, čo viedlo k predpokladu o ich pôvode na území Moravy (ČižmářlČižmářová 2014, 51). Rovnaká výzdoba na drôtených špirálovitých kruhoch rôznych vel'kostí z Býčí skály navyše podla $H$. Parzingera naznačuje, že mohli byt' vyrobené v rovnakej dielni (Parzinger 1995, 45, 46). Nálezy zo Zárub a zo Smoleníc-Molpíra ukazujú, že sa takýto typ šperku objavuje aj na juhozápadnom Slovensku. Navyše, na základe chemického zloženia všetkých troch náramkov zo Zárub sa zdá, že minimálne dva z nich, a to tie so žalud'ovito ukončenými koncami, boli vyrobené z rovnakého bronzového drôtu. Nie je vylúčené, že mohli byt vyrobené práve na hradisku Smolenice-Molpír, kde je doložená aj výroba náramkov typu Býčí skála (pozri Felcan/Stegmann-Rajtár/ Tirpák 2019, 146-151, obr. 4), ktoré sa v nálezových celkoch z moravských lokalít vyskytujú spolu so špirálovitými náramkami.

Depot zo Zárub zrejme môžeme datovat do začiatku stupňa HD, teda do obdobia, kedy sa špirálovité náramky objavujú na území Moravy. 


\section{LITERATÚRA}

Bartík/Farkaš/Jelínek 2019 - J. Bartík/Z. Farkaš/P. Jelínek: Bronzehortfunde aus den Kleinen Karpaten und ihren Vorgebirgsgebieten. Hromadné nálezy bronzov z Malých Karpát a ich podhorských oblastí. In: I. Bazovský/ G. Březinová (ed.): L’udia a hory - Archeologická perspektíva. Interakcie l'udských spoločenstiev horských a podhorských oblastízápadného Slovenska. Zborník SNM. Archeológia. Supplementum 12. Bratislava - Nitra 2019, 15-102.

Bobek 2016 - P. Bobek: Doklady sekundárneho navršovania mohýl v strednej dobe bronzovej v oblasti stredného Podunajska. Študijné zvesti AÚ SAV 60, 2016, 31-49.

Budaj 2006 - M. Budaj: Nové nálezy grošov zo 14. a 15. storočia na Slovensku. Zborník SNM 100. Archeológia 16, 2006, 303-310.

Čambal 2008 - R. Čambal: Dva keltské hroty kopijí z Bukovej. Zborník SNM 102. Archeológia 18, 2008, 241-248.

Čambal 2011 - R. Čambal: Románsky meč z Ostrého kameňa pri Bukovej v Malých Karpatoch. Zborník SNM 105. Archeológia 21, 2011, 159-163.

Čambal 2017 - R. Čambal: Nálezy zbraní z neskorej doby laténskej a doby rímskej z Malých Karpát. Študijné zvesti Aú SAV 61, 2017, 5-12.

Čambal 2020, v tlači - R. Čambal: Variant neskorolaténskej opaskovej zápony typu Voigt A z Bukovej v Malých Karpatoch. Zborník SNM 114. Archeológia 30, 2020, v tlači.

Čižmář/Čižmářová 2014 - M. Čižmář/J. Čižmářová: Pozdně halštatský nález z Pavlovic (okr. Vyškov) a několik dalších halštatských depotů z Moravy. In: J. Čižmářová/ N. Venclová/G. Březinová (ed.): Moravské křižovatky. Střední Podunají mezi pravěkem a historií. Brno 2014, 35-56.

Čižmář/Geislerová 2006 - M. Čižmář/K. Geislerová (ed.): Výzkumy - Ausgrabungen 1999-2004. Brno 2006.

Dušek 1971 - M. Dušek: Slovensko v mladšej dobe halštatskej. Slovenská archeológia 19, 1971, 423-464.

Dušek 1980 - M. Dušek: Pohrebisko ludu stredodunajskej mohylovej kultúry v Smoleniciach. Slovenská archeológia 28, 1980, 341-382.

Rukopis prijatý 19. 8. 2020

Abstract translated by Erika Makarová

Summary translated by Stephanie Staffen

Mgr. Radoslav Čambal, PhD.

SNM-Archeologické múzeum v Bratislave

Žižkova 12

P. O. Box 13

SK - 81006 Bratislava

radoslav.cambal@snm.sk
Dušek/Dušek 1984 - M. Dušek/S. Dušek: Smolenice-Molpír. Befestigter Fürstensitz der Hallstattzeit I. Nitra 1984.

Dušek/Dušek 1995 - M. Dušek/S. Dušek: Smolenice-Molpír. Befestigter Fürstensitz der Hallstattzeit II. Nitra 1995.

Farkaš 2018 - Z. Farkaš: Zásobné jamy v Bukovej pod hradom Ostrý kameň. Historika 1/2018, 4-9.

Felcan/Stegmann-Rajtár/Tirpák 2019 - M. Felcan/S. Stegmann-Rajtár/J. Tirpák: Nové poznatky ku konštrukciám a technológiám výroby šperku z doby halštatskej zo Smoleníc-Molpíra. In: L. Benediková/G. Březinová/ E. Horváthová/S. Stegmann-Rajtár (ed.): Fragmenty času. Venované Elene Miroššayovej k 70. narodeninám. Študijné zvesti AÚ SAV. Supplementum 1. Nitra 2019, 139-155.

Kováč 2006 - J. Kováč: Stredoveký palcát z hradu Ostrý kameň. Zborník SNM 100. Archeológia 16, 2006, 361-368.

Kvetánová 2008 - I. Kvetánová: Rímska plastika z Bukovej. Zborník SNM 102. Archeológia 18, 2008, 111-124.

Makarová 2017 - E. Makarová: Halštatská fáza pohrebiska $v$ Moravičanoch. Dizertačná práca. Filozofická fakulta Masarykovy Univerzity. Brno 2017. Nepublikované.

Parzinger 1995 - H. Parzinger: Die Funde. In: H. Parzinger/ J. Nekvasil/F. E. Barth: Die Býčí skála-Höhle. Ein hallstattzeitlicher Höhlenopferplatz in Mähren. RGF 54. Mainz 1995, 16-92.

Přichystal/Kos 2006 - M. Přichystal/P. Kos: Doba halštatská. In: M. Čižmář/K. Geislerová (ed.): Výzkumy - Ausgrabungen 1999-2004. Brno 2006, 49, 50.

Salaš 2005 - M. Salaš: Bronzové depoty střední až pozdní doby bronzové na Moravě a ve Slezsku. I. Text. Brno 2005.

Siepen 2005 - M. Siepen: Der hallstattzeitliche Arm- und Beinschmuck in Österreich. PBF X/6. Stuttgart 2005.

Stegmann-Rajtár 2002 - S. Stegmann-Rajtár: Früheisenzeitliche Fernverbindungen entlang dem Ostalpenrand. In: A. Lang/V. Salač (Hrsg.): Fernkontakte in der Eisenzeit. Konferenz Liblice 2000. Praha 2002, 254-269.

Šmíd 2005 - M. Šmíd: Prostějov (k. ú. Čechůvky, okr. Prostějov). Přrehled výzkumů 46, 2005, 264.

Mgr. Erika Makarová, Ph.D.

erika.makarova@gmail.com 


\title{
Hoard of Bracelets from the Hallstatt Period from the Záruby Peak in the Little Carpathians
}

\author{
Radoslav Čambal - Erika Makarová
}

SUMMARY

A hoard of three spiral bracelets made of bronze wire (Fig. 2; 3) originate from the highest peak and dominant feature of the Little Carpathians, Záruby (altitude 747.4) in the cadastral district of the municipalities of Buková a Smolenice (Fig. 1; the items are stored in the collections of the Slovak National Museum-Museum of Archaeology in Bratislava under the record numbers AP 75749-AP 75751). It is located in the Buková furrow which was known in the past as the Biskádsky pass and was one of the most important, strategically significant passages through the Carpathians.

The closest analogies to the three spiral bracelets from Záruby are finds from the Molpír hillfort in Smolenice. Bracelet no. 1 (Fig. 2: 1a, 1b), which has multiple profiled endings, has an identical find from gate IV (Dušek/Dušek 1995, pl. 88: 17). A fragment from house 4 (Dušek/Dušek 1984, pl. 37: 14) probably might be an analogy to the other two bracelets, which have a simple acorn-shaped ending (Fig. 2: 2a, b; 3a, b). From Molpír in Smolenice, we have several typologically similar finds of spiral bracelets. These, however, appear not to have any profiled ended (e.g. Dušek/ Dušek 1984, pl. 53: 7; 114: 15, 16; 1995, pl. 34: 4; 45: 9). The spiral bracelets and smaller circles (hair-ring?) made of bronze wire were also found in important numbers in the Býčí skála cave, with both versions presents: specimens with an acorn-shaped ending and with endings decorated with circular grooves (Parzinger 1995, 45, 46, pl. 15-17). Bronze spiral bracelets with an acorn-shaped ending were also part of two hoards from the environment of the Platennice culture in Moravia. In the hoard found at Rýsov hillfort near Provodov (Zlín district), there were four specimens together with further jewellery, namely four bronze closed bracelets with transversal ribs, 29 glass beads and 33 amber beads (ČižmářlČižmářová 2014, 47-50, fig. 9; 10). Two bracelets of this type were also found in a hoard discovered in the grounds of the settlement in Prostějov-Čechůvky (Čižmár̆l Geislerová 2006, 258, 259; Přrichystal/Kos 2006, 50; Šmíd 2005).

Fig. 1. Little Carpathians in the cadastral district of Buková and Smolenice. 1 - site of the find of the hoard of bracelets on the Záruby peak; 2 - Molpír hillfort in Smolenice (author R. Čambal).

Fig. 2. Záruby, cadastral district of Buková and Smolenice. Hoard of bronze bracelets (drawings: archives of the SNM-AM in Bratislava, photo by R. Čambal).

Fig. 3. Záruby, cadastral district of Buková and Smolenice. Hoard of bronze bracelets (photo by R. Čambal).

Fig. 4. Site of the distribution of spiral bracelets made of bronze wire. 1 - Býčí skála; 2 - Prostějov-Čechůvky;
Its composition resembles the previous hoard. The closed cast ribbed bracelets from both hoards are the Býćí skála type, dated to HC2-HD1 (see Parzinger 1995, 36-38, pl. 10). A revision of the material from the Hallstatt part of the burial site in Moravičany (Makarová 2017, 49) has shown that we can encounter this type of jewellery on the territory of the distribution of the Platennice culture in graves, too. In the burial site in Moravičany, the above-mentioned acorn-shaped ending was preserved on a specimen from grave 533, which could be dated to HD based on a bowl with a diagonal bulge.

The hoard of bronze bracelets is most probably linked to the Hallstatt settlement of the nearby hillfort on Molpír in Smolenice, which is $2.5 \mathrm{~km}$ away as birds fly from the site of the find of the bracelets, and with the movement of the population in this region.

Spiral bracelets with profiled endings and endings decorated with an acorn shape were until recently known only from the territory of central Moravia, which led to the supposition that they originated from Moravia (ČižmářlČžmárová 2014, 51). The finds from Záruby and Smolenice-Molpír show that this type of jewellery also occurs in south-western Slovakia. Based on the chemical composition of all three bracelets from Záruby, it appears that at least two of them, those with the acorn-shaped endings, were made from the same bronze wire (Table 1). We cannot exclude that they might have been made in the Smolenice-Molpír hillfort, where there is also evidence of the production of Býći skála type bracelets, which occur in finds from Moravian sites together with spiral bracelets.

We can probably date the hoard from Záruby to the beginning of $\mathrm{HD}$, that is the period when spiral bracelets appear on the territory of Moravia. Taking into account the site of its deposition under the top of a peak, this might point to a ritual subtext.

3 - Moravičany; 4 - Rýsov u Povodova; 5 - Smolenice-Molpír; 6 - Záruby. Legend: variant A - with acorn-shaped endings; variant B - with endings decorated with circular grooves (author E. Makarová).

Table 1. Záruby, cadastral district of Buková and Smolenice. Chemical composition of the bracelets. Results of measurement using the XRF method (measured by R. Čambal). 
